Reprod. Nutr. Dévelop., 1983, 23 (2 A), 217-222.

\title{
Progesterone, estrogen, LH, FSH and PRL concentrations in plasma during the estrous cycle in goat
}

\author{
G. BONO, F. CAIROLI $\left({ }^{*}\right)$, C. TAMANINI, L. ABRATE $\left({ }^{*}\right)$
}

Istituto di Fisiologia Veterinaria, Università di Bologna, via Belmeloro, 8/2, 40126 Bologna, Italy.

$\left.{ }^{*}{ }^{*}\right)$ Istituto di Ostetricia e Ginecologia Veterinaria, Università di Milano, via Celoria, 10, 20133 Milano, Italy.

Summary. Progesterone, estrogen, $\mathrm{LH}, \mathrm{FSH}$ and PRL variations in plasma were measured in 7 goats by RIA. Mean progesterone level was $0.0-0.8 \mathrm{ng} / \mathrm{ml}$ in estrus and $1-4 \mathrm{ng} / \mathrm{ml}$ in diestrus. Estrogen levels ranged from 10 to $20 \mathrm{pg} / \mathrm{ml}$ in diestrus ; around estrus, a peak of $26.9 \pm 3.18 \mathrm{pg} / \mathrm{ml}$ was observed. LH values were $0.5-3.0 \mathrm{ng} / \mathrm{ml}$ with a preovulatory peak $(40.7 \pm 10.12 \mathrm{ng} / \mathrm{ml}) 8$ to $24 \mathrm{~h}$ after the onset of estrus. Except for a peak $(14.0 \pm 3.09 \mathrm{ng} / \mathrm{ml})$ coincident with $\mathrm{LH}$ surge, plasma $\mathrm{FSH}$ level ranged between 2 and $4 \mathrm{ng} / \mathrm{ml}$. PRL level averaged $2-5 \mathrm{ng} / \mathrm{ml}$ in diestrus but high concentrations of this hormone were seen around estrus.

\section{Introduction.}

Studies on hormonal control of the estrous cycle in the goat essentially concern plasma progesterone variations (Heap and Linzell, 1966 ; Thorburn and Schneider, 1972 ; Jones and Knifton, 1972 ; Wentzel, Botha and Viljoen, 1979 ; Kakusya, 1980 ; Thibier, Pothelet and Jeanguyot, 1981). In a preliminary report, Kakusya (1980) described progesterone, estrogen and $\mathrm{LH}$ profiles in female pygmy goats.

The present experiment was conducted to determine progesterone, estrogen, LH, FSH and PRL variations during the different phases of the estrous cycle in the goat.

\section{Material and methods.}

Animals and blood sampling procedure.

Seven virgin alpine goats, aged 7 to 8 months and weighing 25 to $30 \mathrm{~kg}$, were used. The experiment was carried out between the months of November and December; during this period, goats in northern ltaly $\left(45^{\circ} \mathrm{N}\right.$ latitude) show spontaneous sexual activity. Blood samples were collected by jugular venipuncture : io heparinized tubes every 8 hours during the entire estrous cycle. The blood was centrifuged at $2300 \times \mathrm{g}$ for $10 \mathrm{~min}$ at $4{ }^{\circ} \mathrm{C}$, and the plasma thus obtained was stored at $-20{ }^{\circ} \mathrm{C}$ until assay. 


\section{Detection of estrus.}

At every blood sampling, we looked for estrus by examining the external genitalia and the secretion from the vulva of the goats. Furthermore, behavioural patterns, sexual receptivity and interest in the buck were noted.

Hormone assays.

Progesterone. - Progesterone was determined by radioimmunoassay as described by Seren, Leopold and Bolelli (1974). The antiserum, raised in a rabbit to $11 \alpha$-hydroxyprogesterone-hemisuccinate-BSA, was used at a dilution at 1:12 000. Cross-reactions of other steroids were (in \%): 11 $\%$-hydroxyprogesterone : 83.3 ; 11 $\beta$-hydroxyprogesterone : $15.7 ; 21$-hydroxyprogesterone : 4.0 ; $17 \alpha$-hydroxyprogesterone : $1.7 ; 20 \alpha$-dihydroprogesterone $:<0.1$. Assay sensitivity, defined as the mass of hormone required to suppress binding of the labelled hormone to $90 \%$ of the binding achieved with no hormone added (B/Bo), was $21.9 \pm 0.74$ (SEM) $\mathrm{pg} /$ tube. The recovery of $[1,2,6,7]-{ }^{3} \mathrm{H}$ progesterone was $84.77 \pm 1.21 \%$. The blank value obtained by extracting an equal amount of double-distilled water, under the same plasma conditions, was $<0.01 \mathrm{ng} / \mathrm{ml}$.

Estrogens. - Estrogens were determined by RIA as described by Seren, Leopold and Bolelli (1974). The antiserum was raised in a rabbit to estriol-16,17-disuccinate-BSA and used at a dilution of 1:9 000. The values reported were regarded as total estrogen concentrations because this antibody showed the following cross-reactions (\%): estradiol-17 $\beta$ : 100 ; estrone : 92.5 ; estriol : 58.1 ; estradiol-17 $\alpha$ : 51.5. Assay sensitivity was $7.8 \pm 0.53 \mathrm{pg} /$ tube for estradiol- $17 \beta$. Recovery of $[2,4,6,7]-{ }^{3} \mathrm{H}$ estradiol- $17 \beta$ was $79.29 \pm 0.28 \%$. The average blank value obtained was $7.2 \pm 0.53 \mathrm{pg} / \mathrm{ml}$.

Hypophyseal hormones. - LH, FSH and PRL were quantified by a double antibody radioimmunoassay previously validated in this laboratory (Bono, Gaiani and Chiesa, 1980 ; Bono, Gaiani and Seren, 1980). Because of the unavailability of caprine hypophyseal hormones, ovine standard references were used.

- LH: LH was determined by using an antiovine-LH serum (NIH-LH-S20) diluted 1:80 000 with $0.05 \mathrm{M}$ EDTA-PBS $0.1 \%$ BSA containing $1.5 \%$ RGG, $\mathrm{pH}$ 7.5. Labelled antigen was obtained by radioiodinating purified ovine LH (LER1374A). Specific activity of the ${ }^{125}$-labelled antigen was $62.5 \mu \mathrm{Ci} / \mu \mathrm{g}$. A preparation (NIH-LH-S20) was used for the standard curve. Assay sensitivity was $54 \mathrm{pg} /$ tube.

- FSH: An antibovine-FSH serum and a purified bFSH for iodination were used. Both the antiserum and the purified bFSH were kindly supplied by Dr. Cheng. The specific activity of the labelled hormone was $40.6 \mu \mathrm{Ci} / \mu \mathrm{g}$. FSH values were expressed in ng equivalents of LER-1976-A2. Assay sensitivity was $30 \mathrm{pg} /$ tube.

- PRL: An heterologous radioimmunoassay using an anti-bPRL (NIH-PB1) serum diluted 1:80 000 was developed. Purified oPRL (LER 860-2) was used for radioiodination; specific activity was $100 \mu \mathrm{Ci} / \mu \mathrm{g}$. The same preparation (LER 860-2) was used as the reference standard. Assay sensitivity was $140 \mathrm{pg} /$ tube. The interassay coefficient of variation (CV) was $<15 \%$. 
The reliability of the $\mathrm{LH}, \mathrm{FSH}$ and PRL heterologous assays was assessed by : a) comparing the inhibition curves for the oPRL reference standard and PRL in different amounts $(6.25-200 \mu \mathrm{l})$ of caprine plasma (parallelism was always satisfactory) ; b) recovering known amounts $(100,250,500,1000 \mathrm{pg})$ of hypophyseal hormones added to caprine plasma; regression analysis gave correlation coefficients of $0.988,0.922$ and 0.987 for $\mathrm{LH}, \mathrm{FSH}$ and PRL, respectively, and $c$ ) estimating intraassay precision by measuring $P R L$ concentrations in three caprine plasma pools.

\section{Results.}

Mean variations of plasma progesterone, total estrogen, LH, FSH and PRL observed in 7 goats during the 10 days preceding and following ovulatory LH peak are shown in figure 1.

Mean plasma progesterone values during diestrus ranged between 1 and $4 \mathrm{ng} / \mathrm{ml}$. Between the 80th and 56th hour before LH ovulatory peak, plasma progesterone levels suddenly decreased, remained lower than $1 \mathrm{ng} / \mathrm{ml}$ for about 6 days and then gradually increased to typical diestrous values. The plasma progesterone drop occurred 24 to $48 \mathrm{~h}$ before behavioural estrus, whose length varied between 32 and $40 \mathrm{~h}$.

Mean basal estrogen levels ranged between 10 and $19 \mathrm{pg} / \mathrm{ml}$ during the estrous cycle. About $60 \mathrm{~h}$ before $\mathrm{LH}$ peak and simultaneously with progesterone drop, there was an increase in these plasma estrogen concentrations; maximal levels were observed during $\mathrm{LH}$ peak $(26.9 \pm 3.18 \mathrm{pg} / \mathrm{ml})$.

Except during estrus, when there was a remarkable rise in all the animals just after the rapid progesterone decrease and estrogen increase, mean basal LH levels were low $(0.5-3.0 \mathrm{ng} / \mathrm{ml})$ during the entire cycle. The $\mathrm{LH}$ levels returned to basal concentrations after $16 \mathrm{~h}$; maximal levels were $40.7 \pm 10.12 \mathrm{ng} / \mathrm{ml}$. The interval between sexual receptivity and LH surge averaged 8 to $24 \mathrm{~h}$.

Plasma FSH levels ranged between 2 and $4 \mathrm{ng} / \mathrm{ml}$. During the period between the $60 \mathrm{hrs}$ preceding and the $150 \mathrm{hrs}$ following $\mathrm{LH}$ peak, plasma FSH variations were more pronounced. FSH peak $(14.0 \pm 3.09 \mathrm{ng} / \mathrm{ml})$ was temporarily simultaneous with $\mathrm{LH}$ peak.

Mean basal PRL levels averaged $2-5 \mathrm{ng} / \mathrm{ml}$. Between the $32 \mathrm{hrs}$ preceding and the $80 \mathrm{hrs}$ following LH peak, PRL reached concentrations 5 to 10 and, in some cases, 20 times higher than basal levels. In 5 out of 7 goats, the maximal peak $(46,8 \pm 17.2 \mathrm{ng} / \mathrm{ml})$ coincided with the $\mathrm{LH}$ peak. In the other two animals, no significant variation in this hormone was seen.

\section{Discussion.}

The progesterone patterns we observed during the caprine estrous cycle were similar to those reported by Thorburn and Schneider (1972), Jones and Knifton (1972), Wentzel, Botha and Viljoen (1979) and Thibier, Pothelet and Jeanguyot (1981). 

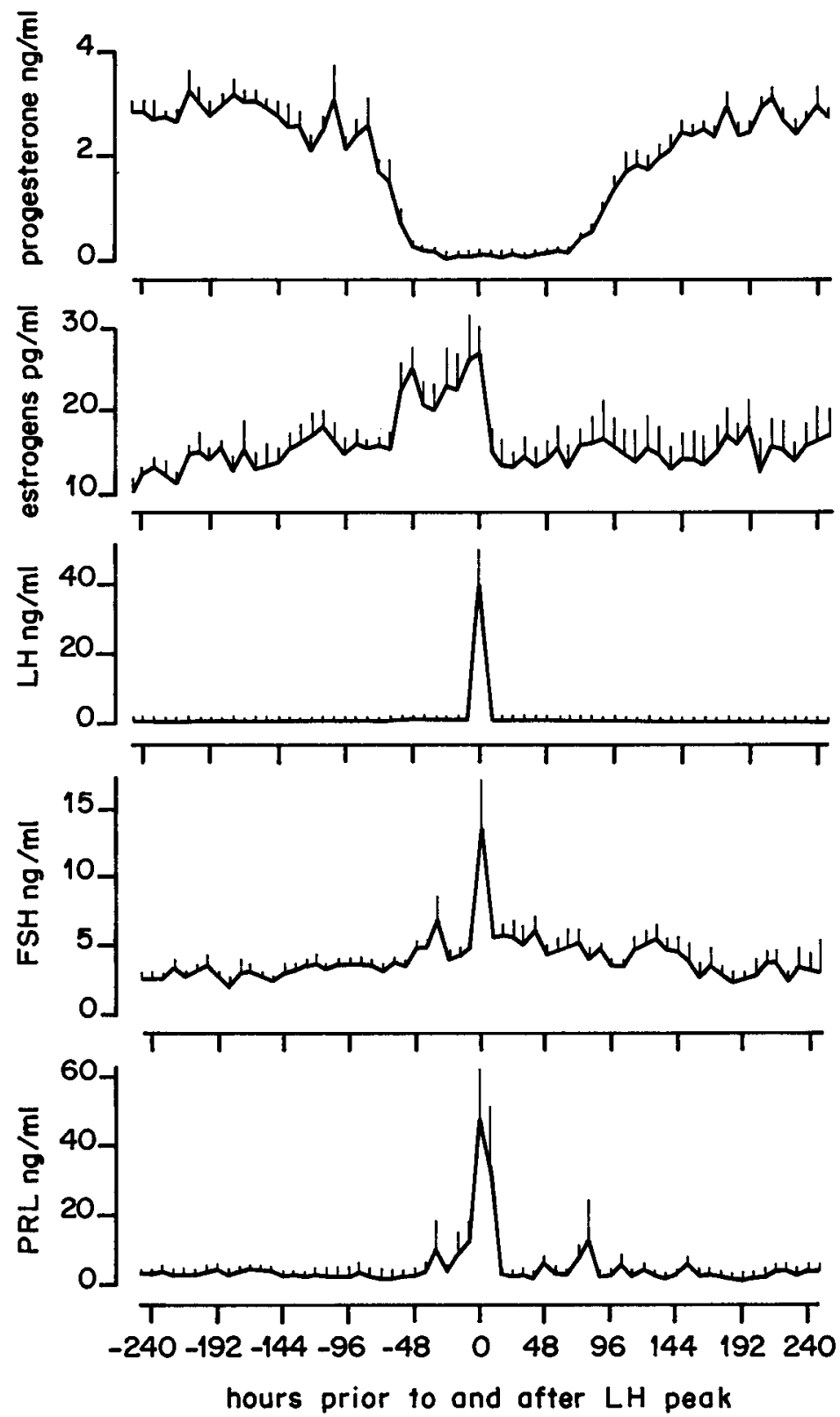

FIG. 1. - Mean variations in plasma progesterone, estrogens, LH, FSH and PRL during the 240 -hour period preceding and following $L H$ peak in 7 goats.

These patterns are characterized by high plasma levels in diestrus and low plasma levels during estrus. A preovulatory estrogen peak was observed in all animals within $48 \mathrm{~h}$ before $\mathrm{LH}$ surge ; maximal values averaged $20-50 \mathrm{pg} / \mathrm{ml}$. 
The estrogen increase coincided with a decrease in the plasma progesterone level ; these events seem to confirm the hypothesis of a feedback mechanism in goats controlling preovulatory LH release, similar to that described in other species, particularly in sheep (Karsch et al., 1978).

The LH surge was observed 8 to $24 \mathrm{~h}$ after the onset of behavioural estrus ; according to Kakusya (1980), LH peak occurs in pygmy goats $6.5 \mathrm{~h}$ after the onset of estrus. According to Bondurant et al. (1981), LH surge is observed for $6 \mathrm{~h}$ preceding or following male receptivity in goats with photoperiodic induction of estrus. Absolute values were not significantly different.

As regards plasma FSH levels, it should be recalled that the rise observed beginning at $60 \mathrm{~h}$ prior to $\mathrm{LH}$ peak might be superimposed essentially to preovulatory estrogen increase. Furthermore, high FSH levels seemed to be closely related to low progesterone concentration.

Patterns of plasma PRL levels are characterized by a maximal peak during estrus; these patterns are similar to those described by Kann and Denamur (1974) in sheep. The mean PRL concentrations in our study are lower than those described by Hart (1973) in anestrous virgin goats or by Bryant and Greenwood (1968) in a lactating goat. These differences in concentration probably depend on the different reproductive statuses of the animals studied.

The high variability of the concentrations we observed and the presence of some occasional increases do not appear to be easily explained in relation to variations in the other hormones we have described.

We conclude that hormonal control of the estrous cycle in goat may be very similar to that hypothesized in other ruminant species as cow and sheep, particularly as regards the relationship between ovarian steroid and gonadotropin (LH and FSH) levels.

Reçu en juillet 1982.

Accepté en octobre 1982.

Acknowledgements. - We wish to thank Dr. L. E. Reichert, Jr. for the ovine LH (NIHLH-S20 and LER-1374A) and ovine PRL (LER-860-2) and Dr. K. W. Cheng for the bovine FSH and anti-bovine FSH serum. This work was supported by a grant from C.N.R. of Italy, 1982, Gruppo Nazionale Scienze Veterinarie.

Résumé. Les concentrations plasmatiques de la progestérone, des œstrogènes, de la $L H$, de la FSH et de la PRL au cours du cycle œstral chez la chèvre.

On a déterminé, au moyen des dosages radioimmunologiques, les variations des concentrations plasmatiques de la progestérone, des œestrogènes, de la $\mathrm{LH}$, de la $\mathrm{FSH}$ et de la PRL chez 7 chèvres.

La progestérone présente une concentration moyenne de $0,0-0,8 \mathrm{ng} / \mathrm{ml}$ au cours de l'œstrus et de 1-4 $\mathrm{ng} / \mathrm{ml}$ au cours de la période interœstrale.

Les taux plasmatiques des œstrogènes qui varient entre $10-20 \mathrm{pg} / \mathrm{ml}$ au cours de la période interœstrale s'élèvent jusqu'à $26,9 \pm 3,18 \mathrm{pg} / \mathrm{ml}$ au moment de l'œestrus.

La LH présente un pic pré-ovulatoire bien défini $(40,7 \pm 10,12 \mathrm{ng} / \mathrm{ml})$ entre la $8^{e}$ et la 24 e heure après le début de l'œestrus; ensuite les taux plasmatiques de cette hormone varient entre $0,5-3,0 \mathrm{ng} / \mathrm{ml}$. 
La FSH présente des niveaux de base de 2 à $4 \mathrm{ng} / \mathrm{ml}$ et un pic pré-ovulatoire $(14,0 \pm$ $3,09 \mathrm{ng} / \mathrm{ml}$ ) qui se superpose à celui de la $\mathrm{LH}$.

Les taux plasmatiques de la PRL varient entre 2 et $5 \mathrm{ng} / \mathrm{ml}$ pendant la période interœstrale mais, au cours des chaleurs ils atteignent des niveaux plus élevés.

\section{References}

BONDURANT R. H., DARIEN B. J., MUNRO C. J., STABENFELDT G. H., WANG P., 1981. Photoperiod induction of fertile oestrus and changes in $\mathrm{LH}$ and progesterone concentrations in yearling dairy goats (Capra hircus). J. Reprod. Fert., 63, 1-9.

BONO G., GAIANI R., CHIESA F., 1980. Bovine LH radioimmunoassay. Arch. vet. It., 31, 64-68.

BONO G., GAIANI R., SEREN E., 1980. PGF-2 $\alpha$ and LH release in immature ewes. $J$. Reprod. Fert., 59, 1-4.

BRYANT GILLIAN D., GREENWOOD F. C., 1968. Radioimmunoassay for ovine, caprine and bovine prolactin in plasma and tissue extracts. Biochem. J., 109, 831-836.

HART I. C., 1973. Basal levels of prolactin in goat blood measured throughout a 24 -h period by a rapid double antibody-solid phase radioimmunoassay. J. Dairy Res., 40, 235-241.

HEAP R. B., LINZELL J. L., 1966. Arterial concentration, ovarian secretion and mammary uptake of progesterone in goats during the reproductive cycle. J. Endocrin., 36, 389-399.

JONES D. E., KNIFTON A., 1972. Progesterone concentration in the peripheral plasma of goats during the oestrus cycle. Res. vet. Sci., 13, 193-195.

KAKUSYA G. R. E., 1980. Reproductive hormone patterns in female pygmy goats. Anim. Breed. Abstr., 48, Abstr. 6791, 806.

KANN G., DENAMUR R., 1974. Possible role of prolactin during the oestrus cycle and gestation in the ewe. J. Reprod. Fert., 39, 473.

KARSCH F. J., LEGAN S. J., RYAN K. D., FOSTER D. L., 1978. The feedback effects of ovarian steroid on gonadotropin secretion, 329-348. In CRIGTON D. B., FOXCROFT G. R., HAYNES N. B., LAMMING G. E., Control of ovulation Butterworths Publ.

SEREN E., LEOPOLD A., BOLELLI G., 1974. Peripheral plasma level of oestrogens and progesterone during the bovine oestrus cycle. Arch. vet. It., 25, 1-20.

THIBIER M., POTHELET D., JEANGUYOT N., 1981. Estrous behavior, progesterone in peripheral plasma and milk in dairy goats at onset of breeding season. J. Dairy Sci, 64, 513-519.

THORBURN G. D., SCHNEIDER W., 1972. The progesterone concentration in the plasma of the goat during the oestrous cycle and pregnancy. J. Endocr., 52, 23-36.

WENTZEL D., BOTHA L. J. J., VILJOEN K. S., 1979. Progesterone levels in the peripheral plasma of the cycling angora goat doe. Agroanimalia, 11, 27-28. 